\title{
The role of the dentist in the diagnosis of ectodermal dysplasia
}

\author{
O papel do cirurgião dentista no diagnóstico da displasia ectodérmica
}

\author{
Kaliandra Torres de QUEIROZ1 \\ Tatiane Fernandes NOVAES 2 \\ José Carlos Pettorossi IMPARATO' \\ Giovani Pinto da COSTA ${ }^{3}$ \\ Gabriela Cunha BONINI ${ }^{1}$
}

\begin{abstract}
Ectodermal dysplasia refers to a hereditary disease that affects the structures derived from the ectoderm. A key feature of this syndrome is multiple missing teeth and teeth with conical shape, affecting the primary and permanent dentition. The pathognomonic facial features make patients very similar to each other. This study aims to report a case in which a 10 years old patient was diagnosed with ectodermal dysplasia during a dental visit; we also discussed the participation of dentists in the diagnostic process of the disease. Caregivers sought dental care, anxious due to several not erupted teeth, and agenesis was confirmed after the panoramic radiograph. Clinically, dry skin, hair and sparse hair, deformed and brittle nails and nose in a "saddle" also called to attention, pointing to a case of ectodermal dysplasia suspect. Thus, the patient and her household were directed to seek medical advice, confirming the diagnosis of the syndrome that supposedly also reached other family members. Since then, the rehabilitation of the patient involved a multidisciplinary treatment planning for prosthetic rehabilitation to treat the agenesis, psycho-pedagogical care support and medical intervention for treatment of hyperopia framework present. The intra-oral characteristics are the primary factors justifying the knowledge of ectodermal dysplasia by dentists, especially the pediatric dentist, who is often the first to diagnose the disease due to the complaint of agenesis reported by parents or patients.
\end{abstract}

Indexing terms: Anodontia. Ectodermal dysplasia. Mouth rehabilitation.

\section{RESUMO}

A displasia ectodérmica (DE) refere-se a uma doença de caráter hereditário que afeta as estruturas derivadas do ectoderma. Uma das principais características desta síndrome é a múltipla ausência de dentes e elementos com formato cônico, afetando a dentição decídua e permanente, além de características faciais patognomônicas que tornam os pacientes bastante parecidos entre si. O presente trabalho tem como objetivo relatar um caso clínico onde uma paciente foi diagnosticada com displasia do ectoderma durante uma consulta odontológica, aos de dez anos de idade; discutimos também a participação do cirurgião-dentista no processo diagnóstico da doença. Os responsáveis pela criança procuraram atendimento odontológico, ansiosos pela não erupção de diversos dentes, cuja agenesia foi confirmada ao exame radiográfico panorâmico. Clinicamente, a pele ressecada, pêlos e cabelos escassos, unhas deformadas e quebradiças e o nariz em forma de "sela" também chamavam atenção, suspeitando-se da manifestação de um caso de displasia ectodérmica. Assim, a paciente e seu núcleo familiar foram encaminhados a procurar orientações médicas, confirmando-se o diagnóstico da síndrome que, supostamente, também atingia outros membros da família. A partir de então, a reabilitação da paciente envolveu um planejamento terapêutico multidisciplinar para reabilitação protética diante das agenesias, atendimento psicopedagógico de suporte e intervenção médica para tratamento do presente quadro de hipermetropia. As alterações dentárias são as características primárias que justificam o conhecimento da displasia ectodérmica pelo cirurgião-dentista, em especial o Odontopediatra, que muitas vezes é o primeiro a diagnosticar a doença pela queixa das agenesias relatadas pelos pais ou pacientes.

Termos de indexação: Anodontia. Displasia ectodérmica. Reabilitação bucal.

\section{INTRODUCTION}

Ectodermal dysplasia is a syndrome which affects the ectoderm structures, such as skin, hair, teeth, nails and glands ${ }^{1}$. The affected individuals present a characteristic facial appearance ${ }^{2}$ as well as signs of hypotrichosis (decreased hair number), hypohidrosis (decreased perspiration) and hypodontia (decrease in number of teeth) ${ }^{3}$, alteration in the teeth shape, eruption delay and in some cases total agenesis ${ }^{4-5}$. The pediatric dentist's role

\footnotetext{
${ }^{1}$ Faculdade São Leopoldo Mandic, Curso de Odontologia, Programa de Pós-Graduação em Odontopediatria. Rua José Rocha Junqueira, 13, Swift, 13045-755, Campinas, SP, Brasil. Correspondência para / Correspondence to: KT QUEIROZ. E-mail: <kalicelinho@hotmail.com>.

${ }^{2}$ Universidade Cruzeiro do Sul, Programa de Pós-Graduação em Odontopediatria. São Paulo, SP, Brasil.

${ }^{3}$ Universidade Federal de São Paulo. São Paulo, SP, Brasil.
} 
and knowledge in the diagnosis process is of utmost importance since ectodermal dysplasia presents a variable degree of early clinical manifestations ${ }^{6}$. Once the diagnosis process has been established, the affected patients can be provided with a multidisciplinary rehabilitation program where self-esteem can be restored enabling. The ectodermal dysplasia syndrome comprises a complex group of disorders ${ }^{7-8}$ with more than 200 different forms identified $^{9}$. Even so, it is considered a rare syndrome with an estimated frequency of 1: 100,000 births ${ }^{10}$, with male preference in a ratio of 5: 111 and a the most common forms of dysplasia are the hypohydrotic syndrome (also known as Clouston syndrome) and the anhidrotic syndrome (Christ SiemenTouraine syndrome), however the hypohydrotic presents more severity. What differs one form of disease from the other is the alteration degree in the glands and the genetic transmission ${ }^{11}$. EDs are caused by specific genes mutations ${ }^{12}$ or specific chromosome coupling ${ }^{13}$. In most cases, the syndrome has a recessive character linked to the $\mathrm{X}$ chromosome ${ }^{6}$, and may also be transmitted as an autosomal dominant chromosome ${ }^{4}$ or autosomal recessive chromosome ${ }^{14-15}$. Other causes can be pointed out such as: exposure to ionizing radiation, endocrine disorders and neoplasms ${ }^{2}$.

Individuals affected by ED present variable clinical and physical manifestations ${ }^{2}$. Hypohidrotic dysplasia is characterized by the classic triad: hypotrichosis (hair loss), hypohidrosis (decreased perspiration) and hypodontia (reduction of the number of teeth) ${ }^{3}$. The hypohidrosis is the most common characteristic of this type of dysplasia and what differentiates it from the hydrophilic form is the perspiration and the sebaceous and mucous glands presenting normal functions ${ }^{11}$.

Due to the reduced number of sweat glands present in the hypohydrotic form, the affected patient presents impaired perspiration leading to hyperthermia, with febrile seizures during childhood, even leading to neurological impairment ${ }^{4}$ with mental retardation which can be observed in 30 to $50 \%$ of the cases $^{16}$. The number of mucous, sebaceous and salivary glands may also be altered, resulting in thick nasal secretions which can trigger respiratory disease development ${ }^{6}$ and also thin, smooth, transparent and dry skin, often presenting an association with atopic dermatitis ${ }^{16}$ or hyperkeratosis in the palm of the hands and feet soles ${ }^{11}$ dry oral mucosa, xerostomia ${ }^{6}$, as well.

The patient may also present atrophic rhinitis (some have no smell or taste), ocular changes causing diminished lacrimation, conjunctivitis, photophobia ${ }^{16}$ and hearing disorders (total or partial deafness), characteristics that vary from one patient to another ${ }^{17}$. Due to the hypotrichosis present in both forms of dysplasia, the hair is usually light, sparse and thin,looking like steel wires and failing in the temporal region ${ }^{18}$. Diminished eyelashes and eyebrows body hair ${ }^{19}$ can be observed, as well. Nails may be dystrophic, thick and brittle ${ }^{19}$ but rarely very deformed ${ }^{16}$.

As hypodontia is concerned, this may compromise the deciduous or permanent dentition, affecting mainly the mandibular incisors, mandibular second molars and maxillary canines. In some cases the child may present total agenesis in the deciduous and permanent dentition, but at a low frequency?.

Dental alterations occur early and should be detected in childhood ${ }^{4}$. Multiple missing teeth and their conical and pointed shape are striking features ${ }^{6}$, together with eruption delay ${ }^{5}$. Hypodontia may lead to an incorrect development of the alveolar process, leading to a decrease in the vertical dimension, alveolar ridge atrophy, labial protuberance ${ }^{4}$ and feeding impairment ${ }^{18}$. On the other hand, despite the dental alterations, the maxillary bone growth develops within normality ${ }^{11}$

Patients' dental enamel thickness is thinner than the normal in the incisal and occlusal regions and its coloration can vary from white to brownish yellow and still show spots in some areas (hypoplasias) ${ }^{2}$. The teeth can also suffer abrasion, cuspid loss, increase in pulp volume, present pointed cuspids and crown diameter reduced in the form of barrel or blackberry. The alveolar ridge is narrow, reduced and shaped like a knife blade ${ }^{19}$. There may be prolonged retention of deciduous teeth prone to ankylosis and supernumerary teeth ${ }^{17}$. Root size may be decreased ${ }^{20}$ and caries increased ${ }^{16}$. Individuals presenting this syndrome have a characteristic face trait, very similar to each other ${ }^{7}$, although some show only slight phenotypic abnormalities ${ }^{9}$. Among the facial features the following can be highlighted: hyperpigmentation at periorbital and perioral areas, fine and linear wrinkles ${ }^{11}$, hypoplasia at the middle third of the face resulting in protruding lips, poorly formed low-set ears, depressed nasal bridge causing a saddle-shaped nose look ${ }^{6}$. Other features can be observed such as: the loss of the face vertical dimension associated with fissures around the mouth giving the child a senile appearance at an early age ${ }^{1}$, prominent frontal bossing, small face ${ }^{4}$, hypotonicity of the perioral musculature ${ }^{2}$ and short stature ${ }^{19}$. In females, the mammary glands are usually hypoplastic or aplastic ${ }^{11}$. 
The diagnosis of the syndrome is essentially clinical and should be based on the patient's anamnesis as well as radiographic examination ${ }^{6}$. In the history provided by the patient, information such as constant fever with no identified cause as well as perspiration impairment ${ }^{11}$ during the first two years of life along with family history of similar clinical features, are essential and useful features for the syndrome diagnosis ${ }^{16}$.

Patients'clinical and physical examination based on facial characteristics faciliate the diagnosis after early age ${ }^{11}$. However, in the neonatal period, this essentially clinical diagnosis is impaired due to normal characteristics being considered normal ${ }^{4}$. Oral radiographic examination (panoramic radiograph of the jaws) will show the absence of permanent teeth6.

Histopathological examination for skin biopsy may also be useful in the diagnosis revealing a flattened epidermis with a decreased number of sebaceous glands and capillary follicles ${ }^{6}$ or even absence of sweat glands ${ }^{1}$.

The final diagnosis can be clarified through genetic tests (genetic mapping) that will show the accurate location of the mutation and which gene is responsible for the disease, an essential piece of information for genetic counseling, in order to avoid consanguineous marriages and anticipate medical care which can help understand mechanisms and identification of the various diseases caused by genes ${ }^{9}$.

The patient should be provided with multidisciplinary treatment ${ }^{21}$ including several specialties such as Dentistry, Medicine (Pediatrics, Dermatology, Otorhinolaryngology, Genetics, Neurology, Ophthalmology, Orthopedics, Plastic Surgery, Speech Therapy, Psychology, etc. $)^{9}$. Care should be provided at patient's early age in order to minimize possible odontological and medical complications $^{11}$ and assure a more favorable prognosis ${ }^{7}$. The dental treatment is long and it must be constantly adapted to infant development and growth ${ }^{7}$. Among oral rehabilitation procedures, the following can be mentioned: the use of removable appliances, fixed prosthesis, partial removable prosthesis with or without expanders, total prosthesis for cases of total anodontia ${ }^{22-23}$, overdentures ${ }^{5}$, osseointegrated implants after the child's growth has ceased $^{4}$, orthodontic appliances, aesthetic restorations of the teeth $t$ presenting shape abnormality ${ }^{17}$. The glass fiber ribbon and composite resin are also an option for conventional space maintainers ${ }^{19}$.
Patient should be periodically followed until optimal growth and the device or prosthesis installed must be replaced ${ }^{4}$, according to the child's growth and until its definitive rehabilitation.

\section{CASE REPORT}

A 10-year-old female patient, leucoderma, attended a Family Health Unit in the city of Santa Luzia, in the municipality of Palmares, State of Pernambuco, Brazil, accompanied by her mother complaining about "lack of some permanent teeth". Other permanent teeth would be "born." After the intra-oral clinical examination, a panoramic radiograph of the jaws was requested confirming the absence of the following teeth: $13,15,17$, $18,23,25,27,28,31,35,37,38,41,45,47$ and 48 . Deciduous teeth 55,65 and 75 were detected according to Figure 1. The patient's oral mucosa was very dry suggesting a decrease in salivary flow. During the anamnesis, the patient's mother informed about dental eruption delay, no history of a consanguineous marriage. The mother also reported a difficulty in controlling the daughter's body temperature and said that her body "almost did not perspire", presenting constant fever, with no identified cause. The patient presented a delay in mental development and underperformed learning tasks when compared to other classmates in the classroom. According to the mother, the child also took time to develop speech. Frequent respiratory problems, rhinitis, and vision problems (hyperopia) have also been reported.

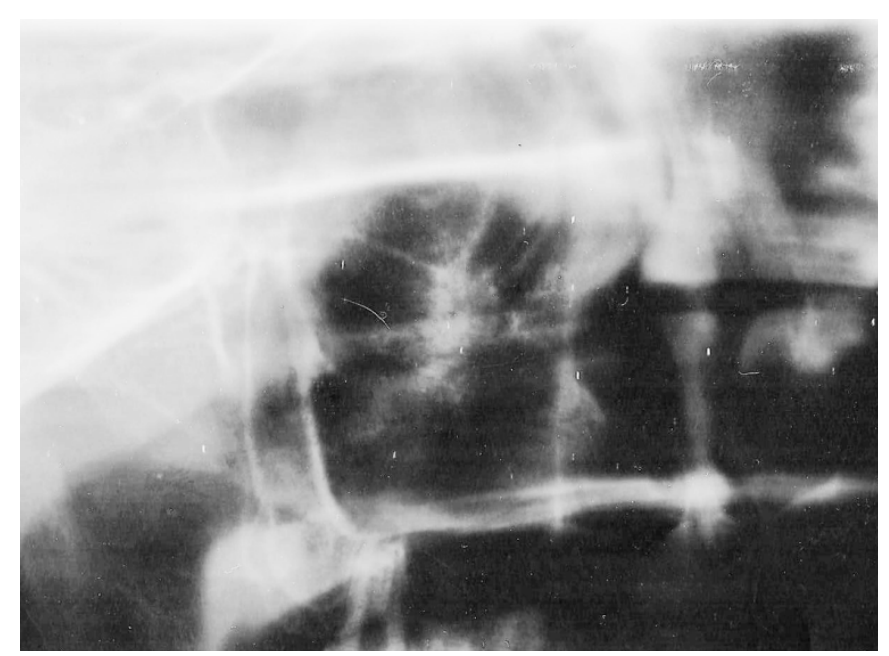

Figure 1. Panoramic radiograph showing several teeth agenesia. 
The extraoral clinical examination showed an ED characteristic face presenting smooth, dry skin, scarce and diminished body hair, sparse eyelashes and eyebrows, deformed and brittle nails, low set ears, saddle-shaped nose, small face, short stature and prominent frontal bossing. Socially, she was a shy and withdrawn child (Figures 2, 3 and 4). Small mammary glands were also reported by to her mother. All these characteristics have led to a Hereditary Ectodermal Dysplasia (EDH) clinical case and the patient was referred to a geneticist evaluation at the Mother and Child Institute of the State of Pernambuco. The physician confirmed the diagnostic hypothesis, based only on the clinical characteristics presented and the classification of the type hypohydrotic, associated to the sweat glands, was added. Since no genetic test was performed, the gene which underwent the mutation responsible for the manifestation of EDH could not be indicated. The patient's karyotype was performed as to add information to the case, and no chromosome anomaly was found. Still under medical evaluation, the patient was also diagnosed with a degree of moderate mental retardation, nervous system disease and hypermetropia with guarded prognosis. Once the diagnostic process was completed, the patient was referred for multidisciplinary treatment, including dental care performed at the local Specialty Center and psychopedagogical follow-up, since the patient reported feeling different from the sister and the other children. Impaired development of routine learning tasks was also reported. Ophthalmologic intervention was also indicated for the treatment of hyperopia. The patient has been monitored by the professionals described every 3 months. As the patient's mother and brother presented similar physical aspects, they underwent a detailed anamnesis and a panoramic x-ray was requested, as well. Although the sibling presented some facial features related to the syndrome, they were mild and almost imperceptible. At clinical and radiographic examination, no missing teeth were found. The mother also presented few facial features, but the dental involvement was remarkable with 11, 12, 16, $17,18,21,22,25,26,28,45,46,47,48,35,36,37,38$ missing teeth. The mother reported in the anamnesis that in adolescence she also had several missing teeth, which suggests that she also presented EDH. The whole family present in this report was never advised about dysplasia.

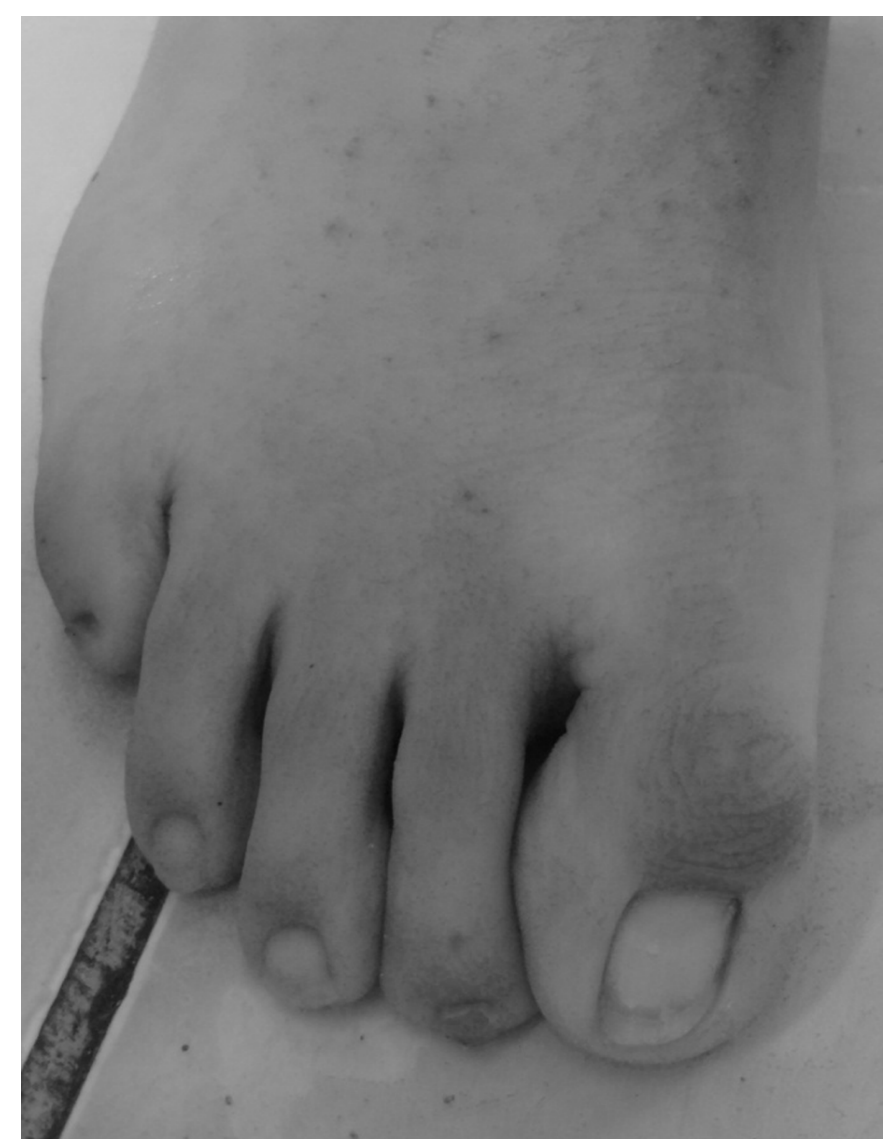

Figure 2. Thick and brittle nails key features of an ectorderm dysplasia patient.

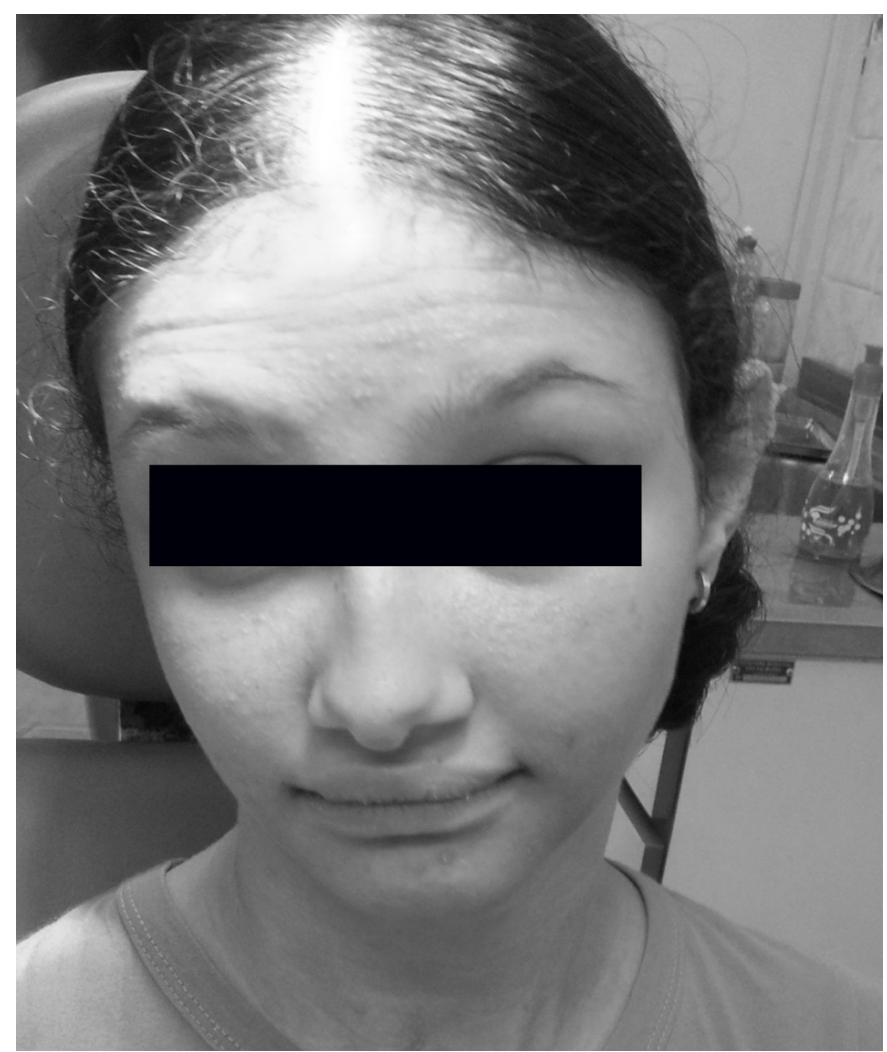

Figure 3. Facial characteristic features of an ED patient. 


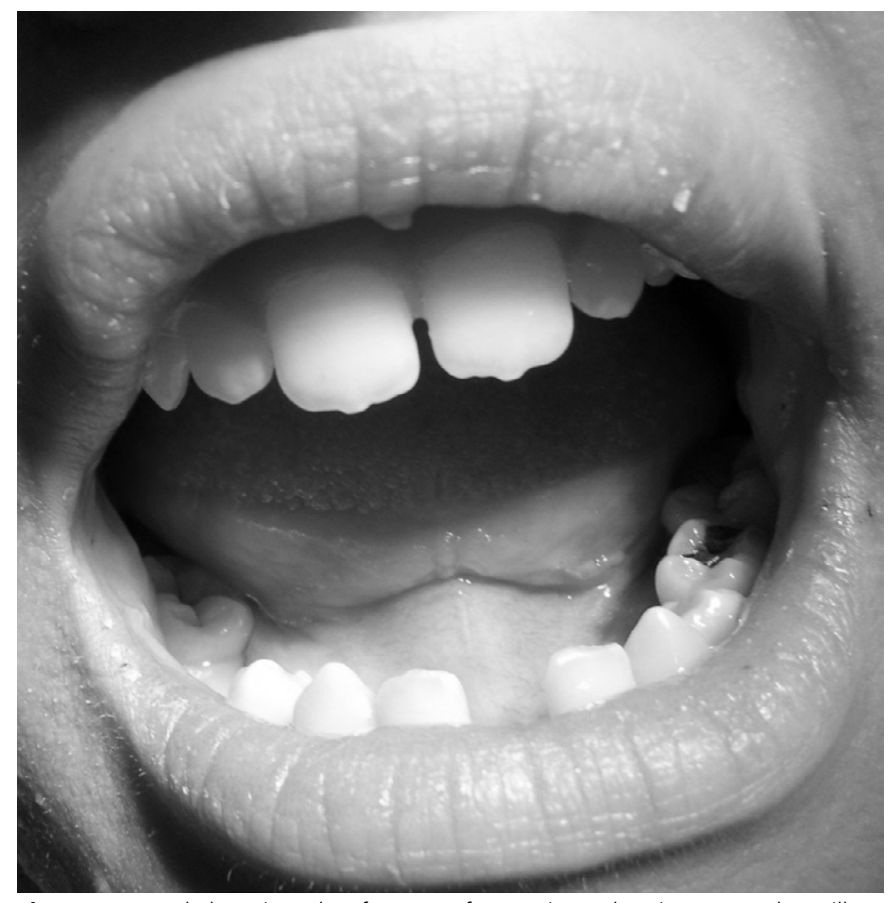

Figure 4. Dental alterations; key features of ED patients showing serrated maxillary incisive teeth.

\section{DISCUSSION}

Ectodermal dysplasia syndrome (ED) affects, among other structures, the teeth, and hypodontia is the most important oral manifestation ${ }^{4}$. For this reason, the role of the dentist in the diagnosis is extremely important, since he may be the first professional to be sought by the patient in order to clarify this complaint. Thus, the need to know these alterations is essential, since sometimes the manifestations presented by the syndrome are subtle and not very noticeable.

The patient of the described clinical case is female, which is not so common, since it is known that for the disease to occur in females, the two affected chromosomes, one of each parent have to be inherited. Women usually carry less severe expressions of this anomaly, presenting little or no evidence of this condition, which impair the clinical disease identification ${ }^{6,18}$. In the present case, unlike what had been described before, in a female patient several characteristics leading to the ectodermal dysplasia were found, which facilitated its identification. Although she was 10 years old, the patient had not yet been diagnosed and oriented regarding the syndrome by any health professional who evaluated her during those years. There were 16 missing permanent teeth as well as several feverish periods with no identified cause, besides obvious facial features, which were essential for the dysplasia detection. Form abnormalities were also found involving the anterior teeth and, thus, causing aesthetic concern ${ }^{7}$. In the present case it was observed that only the maxillary central incisors presented a serrated appearance and irregular borders. Retained deciduous teeth was also diagnosed, an ED common finding ${ }^{24}$. Mental retardation is not specifically related to $E D$, with few reports suggesting any type of neurological deficiency linked to the syndrome ${ }^{8,16}$. In the case presented, the child was diagnosed with moderate mental retardation, and there was insufficient evidence to support its association with the ED diagnosis. Several clinical features are strongly suggestive of the diagnosis of the syndrome, such as the presence of diminished, dry and fine hair, saddle nose, frontal bossing, pointed ears, thick and brittle nails ${ }^{17}$ and hypoplastic mammary glands ${ }^{11}$, besides reduced salivation and respiratory diseases ${ }^{6}$. Despite an estimated incidence of 1:100,000 births ${ }^{6}$, doubts regarding these pathognomonic characteristics of ED which were included in the dental history gave rise to a strong diagnostic hypothesis. The referral of the patient to a medical evaluation confirmed the diagnosis also based on the clinical findings, corroborating with authors who point out an essentially clinical diagnosis for $\mathrm{ED}^{4,6,11}$.

Genetic mapping may also be used in order to identify the genes involved and the accurate location of the mutation, a piece of information of utmost importance in order to provide genetic counseling and also anticipate some medical care ${ }^{25}$. Genetic counseling contraindicates consanguineous marriages in order to prevent such X-linked disorders. Once this syndrome is an X-linked hereditary disorder, even in cases where genetic mapping is not performed, patients should be guided about the genetic pattern of the disease. The treatment of ED patients should combine several health specialties. In most cases, oral rehabilitation includes a fixed, removable prosthesis or dental implant for the recovery of missing teeth $^{26}$. Psychological and emotional effects should also be considered in therapeutic planning ${ }^{11}$. The final objective of any intervention, in the several stages and treatment needs, is to improve life quality of the Ectodermal Dysplasia patients.

\section{CONCLUSION}

Dental alterations, especially agenesis, are important elements in the manifestation of ED and the 
main complaint reported by affected patients, favoring the dentist's knowledge and identification of the syndrome. Through a correct and accurate diagnosis, the need for multidisciplinary therapy can be established in order to promote the physical, social and emotional well-being of the patients.

\section{Collaborators}

KT QUEIROZ has performed the patient's initial and necessary clinical treatment, referred for medical

\section{REFERENCES}

1. Alves MR, Ribeiro PS, Spyrides SMM, Copello RCT, Silva FA. Reabilitação orofuncional em paciente com displasia ectodérmica: relato de caso. Rev Bras Odontol. 2006;63(1/2):5355.

2. Asamoah $A$, Decker AB, Wiktor $A$, Dyke DLV. Child with De novo $\mathrm{t}(1 ; 6)(\mathrm{p} .22 .1 ; \mathrm{p} 22.1)$ translocation and features of ectodermal dysplasia with hypodontia and developmental delay. Am J Med Genet A. 2003;118A(1):82-85

3. Bhalla G, Agrawal KK, Singh K, Singh BP, Goel, P. A preliminary study to analyse the crânio facial growth of an ectodermal dysplasia patient after prosthetic rehabilitation. J Indian Prosthodont Soc. 2013 Mar;13(1):43-8. doi: 10.1007/s13191012-0167-0

4. Corrêa MSNP, Ulson RCB, Rodrigues CRMD, Azevedo AM. Displasia ectodérmica hereditária: revista da literatura com relato de caso clínico. Rev Paul Odontol. 1997 jan-fev;19(1):30-2.

5. Echeverria $S R$, Fernandes $A L$, Politano $G T$, Imparato JCP. Reabilitação estético-funcional em paciente com síndrome da displasia ectodérmica hereditária hidrótica. JBCJ Bras Clin Odontollntegr. 2003 set-out;7(41):417-420.

6. Gupta M, Sundaresh KJ, Batra M, Rathva VJ. An unusual case of ectodermal dysplasia: combating senile features at an early age. BMJ case Reports. 2014;3:2013201225. doi: 10.1136/bcr2013-201225

7. Kishore M, Panat SR, Aggarwal A, Aggarwal N, Upadhyay N, Ajai K, et al. Hypoidrotic ectodermaldysplasia: a case series. J Clin Diagn Res. 2014 jan;8(1):273-275. doi: 10.7860/ JCDR/2014/6597.3951

8. Oliveira TM, Honório HM, Peter EA, Silva SMB, Machado MAAM. Tratamento reabilitador para criança com síndrome da displasia ectodérmica hereditária. Odontol Clin Cient. 2006 outdez;5(4):327-36.

9. Svendsen MT, Henningsen E, Hertz JM, Grejsen DV, Bygum A. A retrospective study of clinical and mutational findings in 45 danish families with ectodermal dysplasia. Acta Derm Venereol. 2014;94(5):531-3.doi:10.2340/00015555-1799

10. Volpato LER, Volpato MCPF, Carvalhosa AA, Palma VC, Borges $\mathrm{AH}$. Ectodermal dysplasia associated with sickle cell disease. treatment, researched articles for literature review and described the clinical case. TF NOVAES has written the abstract and discussion of the case, corrected the text and drafted the necessary documents to prepare the manuscript. JCP IMPARATO assisted in the search of articles for literature. GP COSTA has provided medical information about the syndrome, was responsible for the digitalization of the figures and contributed to the preparation of the manuscript. G BONINI has corrected of the text, searched for articles and contributed to the preparation of the manuscript.

Hindawi Publishing Corporation. Case Rep Dent. 2014; 2014: 314391. doi: 10.1155/2014/314391

11. Amorim RFB, Nuñez MAG, Sales MAO, Rulz PA, Medeiros $A M C$, Freitas RA. Displasia ectodérmica hereditaria. Relato de 3 casos en una família y revisión de la literatura. Rev Assoc Dental Mexicana (Rev ADM). 2002 mar-abr;59(2):67-72

12. Deshmukh S, Prashanth S. Ectodermal dysplasia: a genetic review. Int J Clin Pediatr Dent. 2012 Sep-Dec; 5(3):197-202. doi: 10.5005/jp-journals-10005-1165

13. Sprecher E. Genetic hair and nail disorders. Clin Dermatol. 2005 jan-fev;23(1):47-75.

14. Klein OD, Oberoi S, Huysseune A, Hovorakova M, Peterka M, Peterkova R. Developmental disorders of the dentition: na update. Am J Med Genet C Semin Med Genet. 2013 nov;163(4) doi:10.1002/ajmg:c.31382

15. Sarkar T, Bansal R, Das P. Whole genome sequencing reveals novel no-synonymous mutation in ectodysplasin A (EDA) associated with non-syndromic $X$-linked dominant congenital tooth agenesis. Plos one. 2014 sep;9(9):e10681.

16. Saad CP, Nogueira MF, Tamura BM, Gugé LC. Displasia ectodérmica- relato de caso clínico. BCl. 2000 jul-agoset;27(7):29-31

17. Xavier ASS, Peli PG, Benfatti SV, Bausells J. Displasia ectodérmica anidrótica hereditária: revisão da literatura e relato de um caso clínico. Rev Cienc Odontol. 2002 jan-dez;5(5):81-5.

18. Hand $J$, Rogers RS. Oral manifestations of genodermatoses. Dermatol Clin. 2003;21(1):183-194.

19. Bussadori SK, Mota LJ, Silva PE, Martins MD, Ferrari RAM, Fernandes KPS, et al. Reabilitação bucal na dentadura decídua em criança com displasia ectodérmica: relato de caso clínico. Rev Paul Odontol. 2009 jul-set;31(3):24-27.

20. Kurisu K, Tabata MJ. Human genes for dental anomalies. Oral Dis. 1997;3(4):223-8.

21. Bani M, Tezkirecioglu AM, Akal N, Tuzuner T. Ectodermal dysplasia with anodontia: a reporto $f$ two cases. Eur J Dent. 2010 Apr; 4(2): 215-22.

22. Bala S, Nikhil M, Chugh A, Narval A. Prosthetic Rehabilitation of a child suffering from hypohidrotic ectodermal dysplasia with 
complete anodontia. Int J Clin Pediatr Dent. 2012 May;5(2):14850. doi: 10.5005/jp-journals-10005-1155

23. Singh $T$, Singh $R$, Singh GP, Singh JP. Hypohidrotic ectodermal dysplasia: a felicitous approach to esthetic and prosthetic management. Int J Clin Pediatr Dent. 2013 May-Aug; 6(2): 140145. doi: 10.5005/jp-journals-10005-1207

24. Coelho ASEC, Macho VMP, Andrade DJC, Augusto APCM, Areias CMFG. Prevalence and distribuition of tooth agenesis in a pediatric population: a radiographic study. RGO, Rev Gaúch Odontol. 2012;60(4):503-8.

25. Arte S, Parmanen S, Pirinen S, Alaluusua S, Nieminen P. Candidate gene analysis of tooth agenesis identifies novel mutations in six genes and suggests significant role for WNT and EDA signaling and allele combinations. Plos one. 2013 aug;8(8):e73705
26. Cancino MH, Weber JB, Hellwig I, Oliveira FA. Próteses removíveis em crianças com displasia ectodérmica hipoidrótica (DEH). RGO, Rev Gaúch Odontol. 2002;50(2):111-3.

Received on: 15/3/2016

Final version resubmitted on: 14/6/2016

Approved on: 23/6/2016 